\title{
EFFECT OF ORGANIC AND INORGANIC SALTS ON MYCELIAL GROWTH, SPORULATION AND SPORE GERMINATION OF POTATO POSTHARVEST PATHOGENS
}

\author{
Elsherbiny, A. E. ${ }^{1^{\star}}$ and A. Y. El-Khateeb ${ }^{2}$ \\ ${ }^{1}$ Plant Pathology and ${ }^{2}$ Agric. Chemistry Dept., Fac. Agric., Mans. Univ., \\ Egypt \\ *Corresponding author: sherbiny@mans.edu.eg
}

\begin{abstract}
Ten organic and inorganic salts were tested for suppression of Fusarium solani, a causal agent of potato dry rot, and silver scurf, a postharvest disease of potato tubers caused by Helminthosporium solani. Ammonium acetate, ammonium chloride, ammonium tartarate, calcium chloride dehydrate, magnesium sulfate, potassium dihydrogen phosphate, potassium iodide, sodium benzoate, sodium bicarbonate and sodium sulphate were added to Potato Dextrose Agar (PDA) at concentrations of $0.1 \mathrm{M}, 0.2 \mathrm{M}$ and $0.4 \mathrm{M}$. Several salts significantly inhibited the mycelial growth, sporulation and spore germination of $F$. solani and $H$. solani. The mycelial growth of both tested fungi was completely inhibited by sodium benzoate at the lowest concentration $(0.1 \mathrm{M})$. Sporulation of pathogens was strongly inhibited by sodium benzoate $(100 \%)$ at all concentrations. Some salts, ammonium chloride, ammonium tartarate, calcium chloride dehydrate, potassium dihydrogen phosphate, potassium iodide and sodium sulphate, increased sporulation of $H$. solani at the concentration of $0.1 \mathrm{M}$. Sodium benzoate was also the most effective compound in inhibiting spore germination (100\%) for both fungi, followed by potassium iodide $(93 \%)$ for $F$. solani and ammonium acetate $(88 \%)$ for $H$. solani. Information gathered from this study provides an important basis for further study into the uses of salt compounds for control of postharvest diseases of potato.
\end{abstract}

Keywords: Potato postharvest diseases, Organic and inorganic salts, Alternative controls

\section{INTRODUCTION}

Potato is a major food crop, grown in more than 100 countries in the world. Egyptian potato is preferred worldwide for its taste and meets the international quality standards in terms of disease freeness, shape, size, skin colour, flesh and dry matter content. Egypt's potato production, concentrated in the Nile River delta in the north, has expanded at a rate of more than 5 percent a year. Between 1990 and 2009, annual output rose from 1.6 million tonnes to 4 million tonnes, making Egypt Africa's No. 1 potato producer (http://faostat.fao.org). Egypt also ranks among the world's top potato exporters, in 2004, exports totaled more than 380.000 tonnes of fresh potatoes and 18.000 tonnes of frozen potato products, destined mainly for markets in Europe. Potatoes are Egypt's largest horticultural export commodity. In most recent years the EU has accounted for about 70\%-90\% of Egyptian potato exports (http://www.potato2008.org). 
Postharvest diseases affect a wide variety of crops particularly in developing countries which lack sophisticated postharvest storage facilities. Postharvest decays of fruits and vegetables including decay in potatoes account for significant levels of postharvest losses. It is estimated that about $20-25 \%$ of the harvested fruits and vegetables are decayed by pathogens during postharvest handling even in developed countries (Singh and Sharma, 2007). Infection by fungi and bacteria may occur during the growing season, at harvest time, during handling, storage, transport and marketing, or even after purchase by the consumer. The reduction of losses in perishable food crops because of postharvest diseases has become a major objective of international organizations. The reality is that to adequately feed the world's expected 10 billion people within the next 40 to 50 years, food production efficiency, harvesting and distribution will need to be improved immensely (Campbell, 1998).

Potatoes are susceptible to a variety of post harvest pathogens, including Phytophthora infestans causing late blight, Fusarium solani causing Fusarium dry rot, Pythium ultimum causing Pythium leak and Helminthosporium solani causing silver scurf. Developing in storage, these diseases can infect up to $60 \%$ of stored tubers, leading to significant economic losses (Stevenson et al., 2001).

Fusarium dry rot is one of the most important and common post-harvest diseases of stored potato tubers worldwide. The infection occurs mainly through wounds caused during mechanical harvesting and bulk handling. Dry rot infected tubers are characterized by sunken patches producing white pink fungal cushions. Rotted tubers shrivel and become mummified (Satyaprasad et al., 1997). Control and management of this fungal disease rely on cultural practices such as crop rotation, use of disease-free seed, wound-healing of stored potatoes and minimizing wounds and injuries during harvesting and handling (Secor and Gudmestad 1999). Since cultural practices alone are not always sufficient to effectively control this disease, alternative strategies are needed (Mecteau et al., 2008).

Silver scurf, caused by $\mathrm{H}$. solan, is one of important storage diseases of potato. This disease has become economically important because silver scurf affected potatoes for processing and direct consumption have been rejected by the industry (Frazier et al., 1998). Economic losses have increased since $H$. solani has developed resistance to thiabendazole (TBZ), which is frequently applied to potatoes as a postharvest and seed-piece treatment (Hide et al., 1988; Kawchuk et al., 1994). The economic importance of silver scurf may be due to the higher tuber health standards demanded by processors and changes in marketing of fresh potatoes. Furthermore, high humidity following washing of potatoes destined for market is conducive to sporulation of $H$. solani on infected tubers (Errampalli et al., 2001).

Several organic and inorganic salts are active antimicrobial agents and have been widely used in the food industry. Many of these salts are effective against a range of microorganisms; most have low mammalian toxicity and therefore have potential for postharvest disease control. Salt treatments can inhibit plant pathogens or suppress mycotoxin production (Montville and Goldstein 1989; Singh and Chand 1993; Olivier et al., 1998; Smilanick et al., 
1999; Mann et al., 2004). The efficacy of these organic and inorganic salts depends on the concentration and the target microorganisms (Olivier et al., 1999; Karabulat et al., 2001; Nigro et al., 2006).

The objective of this study was to determine if salt compounds could inhibit the growth and reproduction of economically important potato postharvest pathogens grown on artificial culture media.

\section{MATERIALS AND METHODS}

\section{Fungal isolates}

The isolates of $F$. solani and $H$. solani were obtained from the Plant Pathology Institute, Agricultural Research Center, Egypt. The fungi, isolated from a potato tuber, were maintained on Potato Dextrose Agar (PDA) slants. The agar slants were stored at $4{ }^{\circ} \mathrm{C}$ and served as stock cultures.

\section{Chemicals}

All salts were purchased from El-Nasr Pharmaceutical Chemicals Company, Egypt (Table 1).

Table 1. Organic and inorganic salt compounds used to study inhibitory effects against mycelial growth, sporulation and spore germination in selected potato postharvest pathogens.

\begin{tabular}{llc}
\hline \multicolumn{1}{c}{ Compound } & \multicolumn{1}{c}{ Formula } & Molecular weight \\
\hline Ammonium acetate & $\mathrm{NH}_{4} \mathrm{C}_{2} \mathrm{H}_{3} \mathrm{O}_{2}$ & 77.08 \\
Ammonium chloride & $\mathrm{NH}_{4} \mathrm{Cl}$ & 53.49 \\
Ammonium tartarate & $\mathrm{C}_{4} \mathrm{H}_{12} \mathrm{~N}_{2} \mathrm{O}_{6}$ & 184.00 \\
Calcium chloride dihydrate & $\mathrm{CaCl}_{2} 2 \mathrm{H}_{2} \mathrm{O}$ & 147.02 \\
Magnesium sulfate & $\mathrm{MgSO}_{4} .7 \mathrm{H}_{2} \mathrm{O}$ & 246.48 \\
Potassium dihydrogen phosphate & $\mathrm{KH}_{2} \mathrm{PO}_{4}$ & 174.18 \\
Potassium iodide & $\mathrm{KI}_{4}$ & 166.00 \\
Sodium benzoate & $\mathrm{C}_{7} \mathrm{H}_{5} \mathrm{O}_{2} \mathrm{Na}$ & 144.10 \\
Sodium bicarbonate & $\mathrm{NaHCO}_{3}$ & 84.00 \\
Sodium sulphate & $\mathrm{Na}_{2} \mathrm{SO}_{4}$ & 142.04 \\
\hline
\end{tabular}

\section{Effect of salts on mycelial growth of fungi}

To determine their effect on the mycelial growth of $F$. solani and $H$. solani. The fungi were grown on PDA unamended (control) or amended with test salt at $24{ }^{\circ} \mathrm{C}$. PDA agar disks (diameter $5 \mathrm{~mm}$ ) of actively growing mycelium of fungi were used to inoculate the plates. For each plate, colony diameter was determined after a 7-d incubation period. Colony diameter was measured as the average of the longest diameter and the shortest diameter. Inhibition of mycelial growth was calculated as follows: [(control radial growth - salt amended radial growth) / control radial growth] $\times 100$. The experimental design was a completely randomized block with three replicates.

\section{Effect of salts on sporulation}

Conidia were removed by adding distilled water to each plate and stirring with a sterile glass rod. The resulting spore suspension was filtered 
through two layers of cheesecloth and the spore density of the suspension was determined using a hemacytometer. Spores were counted using a microscope. For each plate, conidia $\mathrm{cm}^{-2}$ of colony was calculated from the number of conidia per plate. Inhibition of conidiation was calculated as follows: [(control number of conidia - salt amended number of conidia) / control number of conidia] $\times 100$. The experimental design was a completely randomized block with three replicates.

\section{Effect of salts on spore germination}

Spore suspensions of each pathogen $\left(1 \mathrm{ml} ; 9 \times 10^{5}\right.$ spores $\left.\mathrm{ml}^{-1}\right)$ were placed in microtubes containing $5 \mathrm{ml}$ of Potato Dextrose Broth (PDB) amended with test salt or unamended (control). The $\mathrm{pH}$ of PDB varied with the salt used and was not changed unless stated otherwise. Microtubes were then incubated at $24{ }^{\circ} \mathrm{C}$ for $24 \mathrm{~h}$. Germination of spores was determined using a hemacytometer. Spores with germ tubes at least half the length of the spore were considered as germinated. Inhibition of spore germination was calculated as follows: [(control spore germination - salt amended spore germination) / control spore germination] x 100. The experimental design was a completely randomized block with three replicates.

\section{Statistical analysis}

Statistical analyses of all experimental data were done using the statistical software package CoStat, (2005). All comparisons were first subjected to one way analysis of variance (ANOVA) and significant differences between treatment means were determined using Duncan's multiple range test at $P<0.05$ as the level of the significance (Duncan, 1955).

\section{RESULTS}

\section{Effect of salts on mycelial growth of potato postharvest pathogens}

Several salts significantly inhibited mycelial growth of $F$. solani and $H$. solani (Table 2). Growth of both tested fungi was completely inhibited when grown on media amended with sodium benzoate at the lowest concentration $(0.1 \mathrm{M})$, whereas magnesium sulfate and ammonium acetate inhibited growth of $F$. solani and $H$. solani to a smaller extent $(62-64 \%)$ at the concentration of $0.4 \mathrm{M}$, respectively. Sodium bicarbonate also inhibited $F$. solani growth by $59 \%$. Six other salts, ammonium acetate, ammonium chloride, ammonium tartarate, calcium chloride dehydrate, potassium dihydrogen phosphate and sodium sulphate inhibited growth of $F$. solani at $0.4 \mathrm{M}$ but to a lesser extent, while three salts for $H$. solani (ammonium tartarate, calcium chloride dehydrate and sodium sulphate), there were no significant $(P<0.05)$ differences between the effects of these compounds. In general, higher concentrations of all tested compounds were toxic to fungal growth.

\section{Effect of salts on sporulation of fungi}

In Petri plates where mycelial growth was observed, the effect of salts on conidiation was also evaluated (Table 3). Complete inhibition of mycelial growth was generally associated with the inhibition of sporulation. 
Table 2. Effect of salts on mycelial growth of Fusarium solani and Helminthosporium solani.

\begin{tabular}{|c|c|c|c|c|c|c|}
\hline \multirow{3}{*}{ Compound } & \multicolumn{6}{|c|}{ Mycelial growth inhibition (\%) $^{\mathrm{a}}$} \\
\hline & \multicolumn{3}{|c|}{ Fusarium solani } & \multicolumn{3}{|c|}{$\begin{array}{c}\text { Helminthosporium } \\
\text { solani }\end{array}$} \\
\hline & $0.1 \mathrm{M}$ & $0.2 \mathrm{M}$ & $0.4 \mathrm{M}$ & $0.1 \mathrm{M}$ & $0.2 \mathrm{M}$ & $0.4 \mathrm{M}$ \\
\hline Ammonium acetate & $28 d^{b}$ & $36 \mathrm{~d}$ & $50 \mathrm{c}$ & $23 \mathrm{~b}$ & $51 \mathrm{~b}$ & $64 \mathrm{~b}$ \\
\hline Ammonium chloride & $28 d$ & $41 \mathrm{c}$ & $51 c$ & $0 \mathrm{~d}$ & $27 d$ & $38 d$ \\
\hline Ammonium tartarate & $32 \mathrm{c}$ & $33 d$ & $49 c$ & $0 \mathrm{~d}$ & $51 \mathrm{~b}$ & $55 c$ \\
\hline Calcium chloride dihydrate & $27 \mathrm{~d}$ & $34 \mathrm{~d}$ & $49 c$ & $0 \mathrm{~d}$ & 19 e & $52 \mathrm{c}$ \\
\hline Magnesium sulfate & $38 \mathrm{~b}$ & $41 \mathrm{c}$ & $62 \mathrm{~b}$ & $0 \mathrm{~d}$ & $8 f$ & $17 \mathrm{f}$ \\
\hline $\begin{array}{l}\text { Potassium dihydrogen } \\
\text { phosphate }\end{array}$ & $34 \mathrm{c}$ & $35 d$ & $52 \mathrm{c}$ & $0 \mathrm{~d}$ & $21 \mathrm{e}$ & $31 \mathrm{e}$ \\
\hline Potassium iodide & $38 b$ & $48 b$ & $58 \mathrm{~b}$ & $0 \mathrm{~d}$ & 19 e & $41 d$ \\
\hline Sodium benzoate & $100 \mathrm{a}$ & $100 \mathrm{a}$ & $100 \mathrm{a}$ & $100 \mathrm{a}$ & $100 \mathrm{a}$ & $100 \mathrm{a}$ \\
\hline Sodium bicarbonate & $37 \mathrm{~b}$ & $46 \mathrm{~b}$ & $59 \mathrm{~b}$ & $16 \mathrm{c}$ & $35 \mathrm{c}$ & $43 d$ \\
\hline Sodium sulphate & $29 \mathrm{~d}$ & $36 \mathrm{~d}$ & $48 \mathrm{c}$ & $0 d$ & $34 \mathrm{c}$ & $51 \mathrm{c}$ \\
\hline
\end{tabular}

${ }^{a}$ Inhibition of mycelial growth was expressed as percentage: [(control radial growth - saltamended radial growth) / control radial growth] x 100. Each value represents the mean of three replicates.

${ }^{b}$ Values within a column followed by a different letter are significantly different according to Duncan's multiple range test $(P=0.05)$.

Table 3. Effect of salts on Fusarium solani and Helminthosporium solani conidiation.

\begin{tabular}{|c|c|c|c|c|c|c|}
\hline \multirow{3}{*}{ Compound } & \multicolumn{6}{|c|}{ Conidiation inhibition (\%) $^{\mathrm{a}}$} \\
\hline & \multicolumn{3}{|c|}{ Fusarium solani } & \multicolumn{3}{|c|}{$\begin{array}{c}\text { Helminthosporium } \\
\text { solani }\end{array}$} \\
\hline & $0.1 \mathrm{M}$ & $0.2 \mathrm{M}$ & $0.4 \mathrm{M}$ & $0.1 \mathrm{M}$ & $0.2 \mathrm{M}$ & $0.4 \mathrm{M}$ \\
\hline Ammonium acetate & $23 \mathrm{~cd}^{\mathrm{b}}$ & 26 de & 32 ef & $9 \mathrm{c}$ & $17 \mathrm{~cd}$ & $32 \mathrm{~b}$ \\
\hline Ammonium chloride & $22 \mathrm{~cd}$ & $28 \mathrm{~d}$ & $30 \mathrm{f}$ & $-14 e$ & $5 \mathrm{~g}$ & $13 \mathrm{~g}$ \\
\hline Ammonium tartarate & $39 \mathrm{~b}$ & $34 \mathrm{c}$ & $37 \mathrm{e}$ & $-4 d$ & $13 \mathrm{de}$ & $21 \mathrm{de}$ \\
\hline Calcium chloride dihydrate & $25 \mathrm{c}$ & $28 d$ & $53 d$ & $-6 d$ & 12 ef & $25 \mathrm{~cd}$ \\
\hline Magnesium sulfate & $35 \mathrm{~b}$ & $48 \mathrm{~b}$ & $65 \mathrm{~b}$ & $15 \mathrm{~b}$ & $19 \mathrm{c}$ & $28 \mathrm{bc}$ \\
\hline $\begin{array}{l}\text { Potassium dihydrogen } \\
\text { phosphate }\end{array}$ & $18 d$ & $23 \mathrm{e}$ & $54 \mathrm{~cd}$ & $-17 e$ & $7 \mathrm{fg}$ & $15 \mathrm{fg}$ \\
\hline Potassium iodide & $37 \mathrm{~b}$ & $47 \mathrm{~b}$ & $64 \mathrm{~b}$ & $-13 e$ & $-7 \mathrm{~h}$ & $18 \mathrm{efg}$ \\
\hline Sodium benzoate & $100 a$ & $100 \mathrm{a}$ & $100 a$ & $100 \mathrm{a}$ & $100 \mathrm{a}$ & $100 a$ \\
\hline Sodium bicarbonate & $22 \mathrm{~cd}$ & $22 \mathrm{e}$ & $59 \mathrm{bc}$ & $19 \mathrm{~b}$ & $29 \mathrm{~b}$ & $32 b$ \\
\hline Sodium sulphate & $23 c$ & $26 \mathrm{de}$ & 32 ef & $-12 \mathrm{e}$ & 9 efg & 20 def \\
\hline
\end{tabular}

${ }^{a}$ Inhibition was expressed as percentage: [(control number of conidia - salt-amended number of conidia) / control number of conidia] $x 100$. Each value represents the mean of three replicates.

${ }^{b}$ Values within a column followed by a different letter are significantly different according to Duncan's multiple range test $(P=0.05)$.

Therefore, compounds which completely inhibited mycelial growth also tended to completely inhibit sporulation at the same concentration. There were, however, compounds which strongest inhibitor against sporulation without inhibiting mycelial growth at the same concentration.Sodium 
benzoate was completely inhibited sporulation of tested fungi by $100 \%$ at all concentrations, followed by magnesium sulfate and potassium iodide for $F$. solani (65 and 64\%) and ammonium acetate and sodium bicarbonate for $\mathrm{H}$. solani $(32 \%)$ at $0.4 \mathrm{M}$. There was enhanced or increased sporulation observed with $H$. solani grown on media amended with ammonium chloride, ammonium tartarate, calcium chloride dehydrate, potassium dihydrogen phosphate, potassium iodide and sodium sulphate at $0.1 \mathrm{M}$.

\section{Effect of salts on spore germination of selected potato pathogens}

Sodium benzoate showed the strongest inhibition of spore germination amongst tested pathogens at all concentrations (Table 4). Potassium iodide was the second best, which exhibited $93 \%$ inhibition of spore germination of $F$. solani, followed by magnesium sulfate and sodium bicarbonate by 91 and $89 \%$ at concentration of $0.4 \mathrm{M}$, respectively. For $H$. solani, ammonium acetate, potassium iodide, sodium sulphate and magnesium sulfate suppressed spore germination by $88-80 \%$, but there were no significant $(P<0.05)$ differences between the effects of these compounds. However, the lowest effective compound was sodium bicarbonate, which induced inhibition in spore germination by $53 \%$ and ammonium tartarate for F. solani by $57 \%$.

Table 4. Effect of salts on spore germination of Fusarium solani and Helminthosporium solani.

\begin{tabular}{|c|c|c|c|c|c|c|}
\hline \multirow{3}{*}{ Compound } & \multicolumn{6}{|c|}{ Spore germination inhibition (\%) $^{a}$} \\
\hline & \multicolumn{3}{|c|}{ Fusarium solani } & \multicolumn{3}{|c|}{$\begin{array}{c}\text { Helminthosporium } \\
\text { solani }\end{array}$} \\
\hline & $0.1 \mathrm{M}$ & $0.2 \mathrm{M}$ & $0.4 \mathrm{M}$ & $0.1 \mathrm{M}$ & $0.2 \mathrm{M}$ & $0.4 \mathrm{M}$ \\
\hline Ammonium acetate & $32 e^{b}$ & $42 \mathrm{~d}$ & $59 \mathrm{e}$ & $33 \mathrm{~d}$ & $59 \mathrm{c}$ & $88 \mathrm{~b}$ \\
\hline Ammonium chloride & $30 \mathrm{e}$ & $45 d$ & $62 \mathrm{e}$ & $22 \mathrm{e}$ & $47 \mathrm{e}$ & $55 \mathrm{f}$ \\
\hline Ammonium tartarate & 33 e & $41 \mathrm{~d}$ & $57 \mathrm{e}$ & $21 \mathrm{e}$ & $56 \mathrm{~cd}$ & $67 \mathrm{de}$ \\
\hline Calcium chloride dihydrate & $56 \mathrm{~d}$ & $72 \mathrm{~b}$ & $84 \mathrm{~cd}$ & $40 \mathrm{c}$ & $57 \mathrm{~cd}$ & $72 \mathrm{~cd}$ \\
\hline Magnesium sulfate & $74 \mathrm{~b}$ & $78 \mathrm{~b}$ & $91 \mathrm{bc}$ & $47 \mathrm{~b}$ & $64 \mathrm{c}$ & $80 \mathrm{bc}$ \\
\hline $\begin{array}{l}\text { Potassium dihydrogen } \\
\text { phosphate }\end{array}$ & $55 d$ & $62 c$ & $83 d$ & 25 e & $44 \mathrm{e}$ & 62 ef \\
\hline Potassium iodide & $64 \mathrm{c}$ & $71 \mathrm{~b}$ & $93 a b$ & $41 \mathrm{bc}$ & $71 \mathrm{~b}$ & $88 \mathrm{~b}$ \\
\hline Sodium benzoate & $100 \mathrm{a}$ & $100 \mathrm{a}$ & $100 \mathrm{a}$ & $100 \mathrm{a}$ & $100 \mathrm{a}$ & $100 \mathrm{a}$ \\
\hline Sodium bicarbonate & $60 \mathrm{~cd}$ & $72 \mathrm{~b}$ & $89 \mathrm{bcd}$ & $33 d$ & $46 \mathrm{e}$ & $53 \mathrm{f}$ \\
\hline Sodium sulphate & 33 e & $42 \mathrm{~d}$ & $63 \mathrm{e}$ & $22 \mathrm{e}$ & $50 \mathrm{de}$ & $84 \mathrm{~b}$ \\
\hline
\end{tabular}

a Inhibition of spore germination was expressed as percentage: [(control spore germination - salt-amended spore germination) / control spore germination] x 100 . Each value represents the mean of three replicates.

${ }^{b}$ Values within a column followed by a different letter are significantly different according to Duncan's multiple range test $(P=0.05)$.

\section{DISCUSSION}

The present study shows that certain salt compounds may provide effective options for the control of dry rot and silver scurf in potato. All of the compounds tested indicated varying degrees of the inhibition of $F$. solani and 
H. solani. Therefore this study demonstrates how some of the more effective test compounds could be integrated into a post-harvest disease controlling strategy for potatoes. Several of the test compounds are currently approved for use on processed food, which may hasten the registration process to allow the use of these compounds in a post-harvest disease control situation. Many of these compounds may provide a viable alternative to synthetic fungicides and bactericides currently available on the market.

The present study showed that $F$. solani and $H$. solani are strongly affected by several organic and inorganic salts. Indeed, the mycelial growth, sporulation and spore germination of fungi was completely inhibited by sodium benzoate at all concentrations $(0.1,0.2$ and $0.4 \mathrm{M})$. Potassium sorbate and sodium benzoate $(0.2 \mathrm{M})$ have been shown to completely inhibit growth of the economically important potato pathogens $\mathrm{H}$. solani (Hervieux et al., 2002) and F. sambucinum (Mecteau et al., 2002), which agrees with the results of the present study. The various modes of action of weak acid preservatives are through membrane disruption (Bracey et al., 1998; Palou et al., 2001), inhibition of essential metabolic functions, stresses on $\mathrm{pH}$ homeostasis and through the accumulation of toxic anions within the cell (Mitchell and Walters 2004). The principle mode of action of weak acid preservatives, however, is believed to be the passage of the undissociated compound through the plasma membrane; once inside the cell in a higher $\mathrm{pH}$ environment, the acid dissociates causing an accumulation of protons and anions which cannot re-cross the plasma membrane (Brul and Coote, 1999; Droby et al., 2003).

The present study also revealed that the magnesium sulfate, among all compounds tested except sodium benzoate, was the strongest inhibitor against $F$. solani growth at $0.4 \mathrm{M}$, inducing $62 \%$ reduction in its mycelia growth, while potassium iodide decreased the fungal growth by $58 \%$. Also, magnesium sulfate was the most effective compound against sporulation followed by potassium iodide, which reduced conidiation by 65 and $64 \%$, respectively. Whereas, potassium iodide prevented more than $93 \%$ of fungal spores to germinate. This was followed by magnesium sulfate, which produced $91 \%$ inhibition in spore germination (Fig. 1). Ammonium acetate had the highest inhibition effect on $H$. solani growth, which caused $64 \%$ reduction in the fungal growth. This compound also strongly suppressed the spore germination by more than $88 \%$, whereas it exhibited $32 \%$ inhibition against sporulation. Salts that inhibited $F$. solani or $H$. solani mycelial growth generally inhibited sporulation and spore germination. However, magnesium sulfate, potassium dihydrogen phosphate and potassium iodide were shown to inhibit spore germination without affecting mycelial growth for $\mathrm{H}$. solani at $0.4 \mathrm{M}$ (Fig. 2). The comparison of the inhibitory effect of the various salts permits the identification of the ions affecting fungi. 


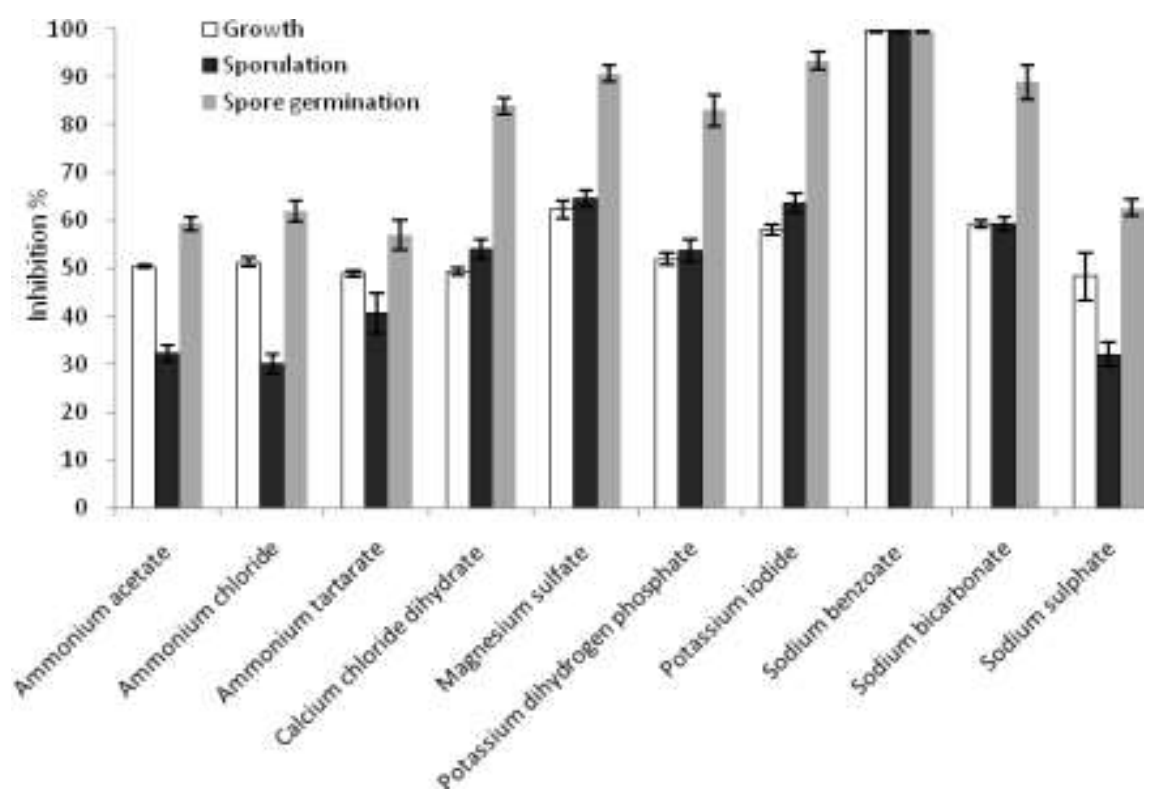

Fig. 1. Effect of organic and inorganic salts on mycelial growth, sporulation and spore germination of Fusarium solani (mean \pm s.e) at the concentration of $0.4 \mathrm{M}$.

The development of resistance by numerous fungal pathogens to synthetic fungicides, such as benzimidazoles and dicarboximides (PetsikosPanayotarou et al., 2003), is also a serious problem with a negative impact on the availability of effective products (Peters et al., 2001). The often long pre-harvest interval (PHI) of synthetic fungicides, to prevent them from entering the food chain, can also substantially reduce their efficacy (Biggs 1999).

In view of this study, it is observed that there is a potential for the use of organic and inorganic compounds to inhibit pathogens responsible for postharvest diseases of potato. There may be a possibility that salt compounds could control post-harvest disease of potato. The prospect of using these compounds as post-harvest disease treatments needs to be examined and may have several advantages for conventional potato production. The application methods for the test compounds must also be examined to maximize product coverage to all tubers.

With the accessibility of many salt compounds and preservatives at a relatively low cost, it is possible that many salt compounds could be adopted by producers. There is presently a trend towards the reduction of synthetic fungicides in agriculture and the use of organic and inorganic salt compounds may provide a compromise as although the compounds may be synthesized artificially, many show a relatively low toxicity compared to commercially available chemical fungicides. Many of the test compounds are presently used in the food processing industry and are generally regarded as safe for 
human consumption at the appropriate concentration. Salt compounds may be implemented as part of a sustainable integrated pest management strategy for post-harvest plant disease.

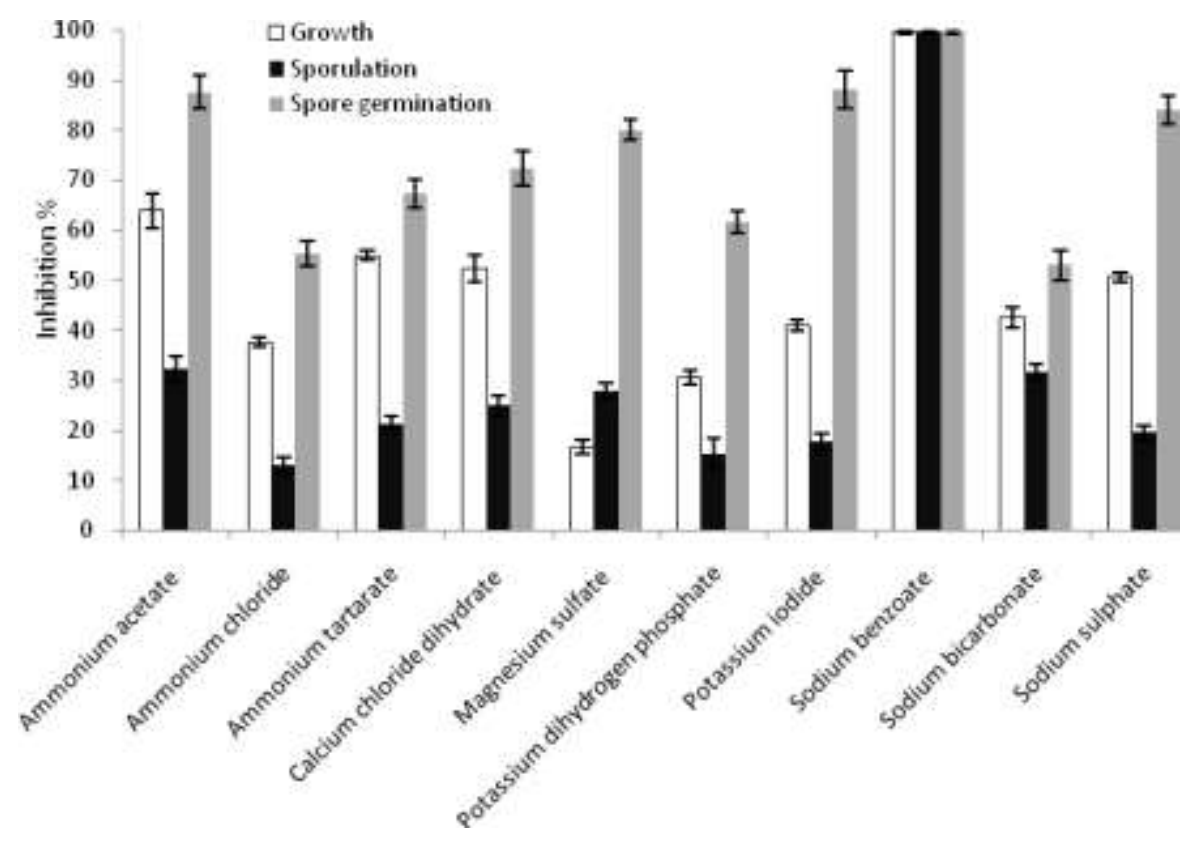

Fig. 2. Effect of organic and inorganic salts on mycelial growth, sporulation and spore germination of Helminthosporium solani (mean \pm s.e) at the concentration of $0.4 \mathrm{M}$.

\section{REFERENCES}

Biggs, A. R. (1999). Effects of calcium salts on apple bitter rot caused by two Colletotrichum spp. Plant Dis 83, 1001-1005.

Bracey, D., Holyoak, C. D. and Coote, P. J. (1998). Comparison of the inhibitory effect of sorbic acid and amphotericin B on Saccharomyces cerevisiae: is growth inhibition dependant on reduced intracellular $\mathrm{pH}$. J. Appl. Microbiol. 85, 1056-1066.

Brul, S. and Coote, P. (1999). Preservative agents in foods - mode of action and microbial resistance mechanisms, a review. Int. J. Food Microbiol. $50,1-17$.

Campbell, C. L. (1998). Food security and plant pathologists. Phytopathol. News 32, 70.

CoStat program, Version 6.311 (2005). CoHort Software, 798 Lighthouse Ave. PMB 320, Monterey, CA, 3940, USA. (http://www.cohort.com). 
Droby, S., Wisniewski, M., El Ghaouth, A. and Wilson, C. (2003). Influence of food additives on the control of postharvest rots of apple and peach and efficacy of the yeast-based biocontrol product Aspire. Postharvest Biol. Technol. 27, 127-135.

Duncan, D. (1955). Multiply range and multiple $\mathrm{F}$ test. Biometrics 11 , $1-42$.

Errampalli, D., Saunders, J. M. and Holley, J. D. (2001). Emergence of silver scurf (Helminthosporium solani) as an economically important disease of potato. Plant Pathology 50, 141-153.

Frazier M. J., Shetty, K. K., Kleinkopf, G. G. and Nolte, P. (1998). Management of silver scurf (Helminthosporium solani) with fungicide seed treatments and storage practices. American Journal of Potato Research 75, 129-35.

Hervieux, V., Yaganza, E. S., Arul, J. and Tweddell, R. J. (2002). Effect of organic and inorganic salts on the development of Helminthosporium solani, the causal agent of potato silver scurf. Plant Dis. 86, 1014-1018.

Hide, G. A., Hall, S. M. and Boorer, K. J. (1988). Resistance to thiabendazole in isolates of Helminthosporium solani, the cause of silver scurf disease of potatoes. Plant Pathol. 37, 377-380.

Karabulat, O. A., Lurie, S. and Droby, S. (2001). Evaluation of the use of sodium bicarbonate, potassium sorbate and yeast antagonists for decreasing postharvest decay of sweet cherries. Postharvest Biol. Technol. 23, 233-236.

Kawchuk, L. M., Holley, J. D., Lynch, D. R. and Clear, R. M. (1994). Resistance to thiabendazole and thiophanate-methyl in Canadian isolates of Fusarium sambucinum and Helminthosporium solani. Am. Potato J. 71, 185-192.

Mann, R. L., Kettlewell, P. S. and Jenkinson, R. (2004). Effect of foliarapplied potassium chloride on septoria leaf blotch of winter wheat. Plant Pathol. 53, 653-659.

Mecteau, M. R., Arul, J. and Tweddell, R. J. (2002). Effect of organic and inorganic salts on the growth and development of Fusarium sambucinum, a causal agent of potato dry rot. Mycol. Res. 106, 688696.

Mecteau, M. R., Arul, J. and Tweddell, R. J. (2008). Effect of different salts on the development of Fusarium solani var. coeruleum, a causal agent of potato dry rot. Phytoprotection 89, 1-6.

Mitchell, A. F. and Walters, D. R. (2004). Potassium phosphate induces systemic protection in barley to powdery mildew infection. Pest Manag. Sci. 60, 126-134.

Montville, T. J. and Goldstein, P. K. (1989). Sodium bicarbonate inhibition of aflatoxigenesis in corn. J. Food Prot. 52, 45-48.

Nigro, F., Schena, L., Ligorio, A., Pentimone, I., Ippolito, A. and Salerno, M. G. (2006). Control of table grape storage rots by pre-harvest applications of salts. Postharvest Biol. Technol. 42, 142-149.

Olivier, C., Halseth, D. E., Mizubuti, E. S. G. and Loria, R. (1998). Postharvest application of organic and inorganic salts for suppression of silver scurf on potato tubers. Plant Dis. 82, 213-217. 
Olivier, C., MacNeil, C. R. and Loria, R. (1999). Application of organic and inorganic salts to field-grown potato tubers can suppress silver scurf during potato storage. Plant Dis. 83, 814-818.

Palou, L., Smilanick, J. L., Usall, J. and Vinas, I. (2001). Control of postharvest blue and green molds of oranges by hot water treatment, sodium carbonate, and sodium bicarbonate. Plant Dis $85,371-376$.

Peters, R. D., MacDonald, I. K., Maclsaac, K. A. and Woodworth, S. (2001). First report of thiabendazole-resistant isolates of Fusarium sambucinum infecting stored potatoes in Nova Scotia. Can. Plant Dis. 85, 1030.

Petsikos-Panayotarou, N., Markellou, E., Kalamarakis, A. E., Kyriakopoulou, D. and Malathrakis, N. E. (2003). In vitro and in vivo activity of cyprodinil and pyrimethanil on Botrytis cinerea isolates resistant to other botryticides and selection for resistance to pyrimethanil in a greenhouse population in Greece. Eur. J. Plant Pathol. 109, 173-182.

Satyaprasad, K., Bateman, G. L. and Read, P. J. (1997). Variation in pathogenicity on potato tubers and sensitivity to thiabendazole of the dry rot fungus Fusarium avenaceum. Potato Research 40, 357-365.

Secor, G. A. and Gudmestad, N. C. (1999). Managing fungal diseases of potato. Canadian Journal of Plant Pathology 21, 213-221.

Singh, D. and Sharma, R. R. (2007). Postharvest diseases of fruit and vegetables and their management. In: Sustainable Pest Management (Eds) Prasad, D., Daya Publishing House, New Delhi, India.

Singh, S. N. and Chand, L. (1993). Inhibition of aflatoxin production by garlic extract and sodium bicarbonate. Crop Res. 6, 149-154.

Smilanick, J. L., Margosan, D. A., Mlikota, F., Usall, J. and Michael, I. F. (1999). Control of citrus green mold by carbonate and bicarbonate salts and the influence of commercial postharvest practices on their efficacy. Plant Disease 83, 139-145.

Stevenson, W. R., Loria, R., Franc, G. D., and Weingartner, D. P. (2001). Compendium of potato diseases, $2^{\text {nd }}$ edition. APS Press, USA. 
تأثير بعض مركبات الأملاح العضوية وغير العضوية على نمو وتجرثم وإنبات

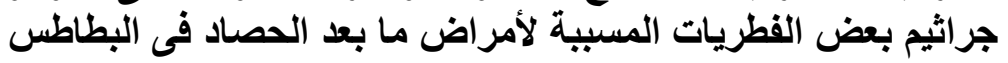

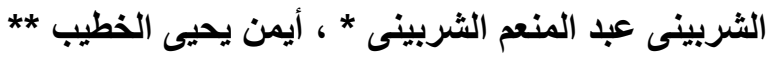

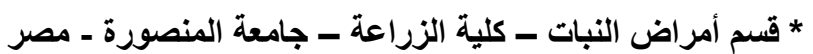

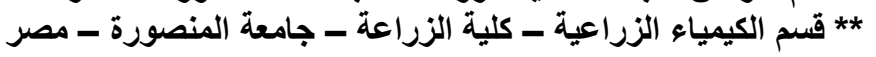

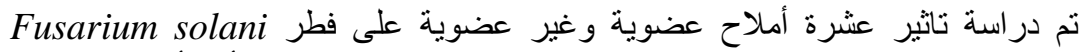

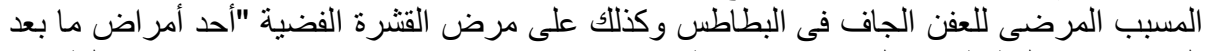

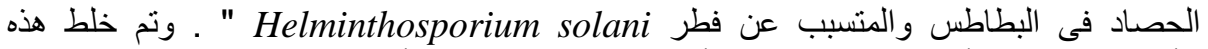

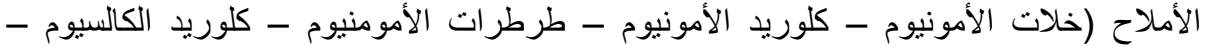

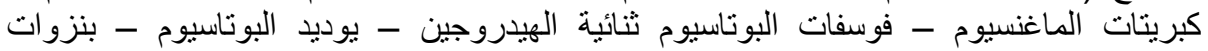

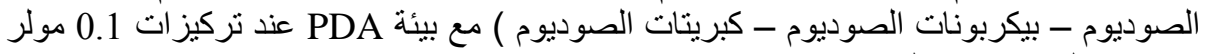

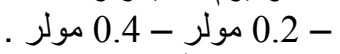

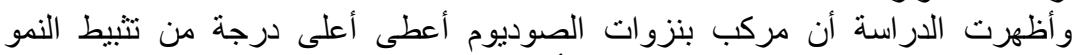

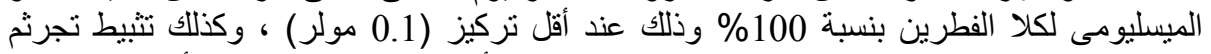

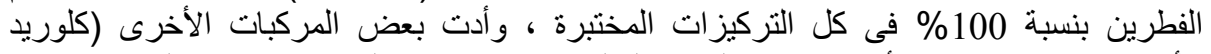

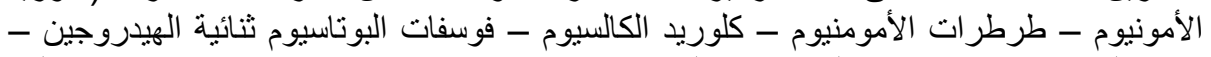

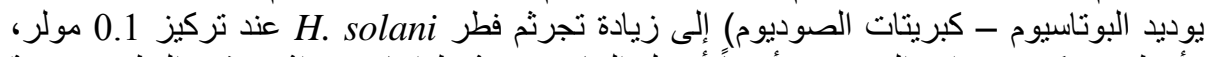

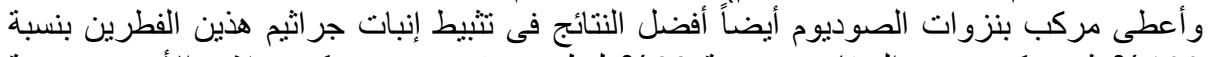

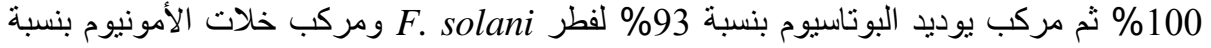

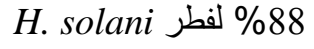

كلية الزراعة - جامعة المنصورة كلية الزراعة - جامعة المنصورة
قام بتحكيم البحث

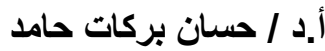

أ. أد / محمود احمد المزاتى جامي 